United Nations Educational Scientific and Cultural Organization and

International Atomic Energy Agency

THE ABDUS SALAM INTERNATIONAL CENTRE FOR THEORETICAL PHYSICS

\title{
CRUST AND UPPER MANTLE STRUCTURE IN THE CARIBBEAN REGION BY GROUP VELOCITY TOMOGRAPHY AND REGIONALIZATION
}

\author{
O’Leary González ${ }^{1}$, Leonardo Alvarez \\ Centro Nacional de Investigaciones Sismológicas, Ministerio de Ciencia, Tecnología y Medio \\ Ambiente, Calle 17 \# 61, Rpto. Vista Alegre, Santiago de Cuba, 90400, Cuba \\ Giordano Chimera \\ Department of Earth Sciences, University of Trieste, via Weiss 4, Trieste, Italy \\ and \\ Giuliano F. Panza \\ Department of Earth Sciences, University of Trieste, via Weiss 4, Trieste, Italy \\ and \\ The Abdus Salam International Centre for Theoretical Physics, SAND group, Trieste, Italy
}

MIRAMARE -TRIESTE

April 2004

\footnotetext{
${ }^{1}$ oleary@cenais.ciges.inf.cu
} 


\begin{abstract}
An overview of the crust and upper mantle structure of the Central America and Caribbean region is presented as a result of the processing of more than 200 seismograms recorded by digital broadband stations from SSSN and GSN seismic networks. By FTAN analysis of the fundamental mode of the Rayleigh waves, group velocity dispersion curves are obtained in the period range from $10 \mathrm{~s}$ to $40 \mathrm{~s}$; the error of these measurements varies from 0.06 and $0.10 \mathrm{~km} / \mathrm{s}$.

From the dispersion curves, seven tomographic maps at different periods and with average spatial resolution of $500 \mathrm{~km}$ are obtained. Using the logical combinatorial classification techniques, eight main groups of dispersion curves are determined from the tomographic maps and eleven main regions, each one characterized by one kind of dispersion curves, are identified. The average dispersion curves obtained for each region are extended to $150 \mathrm{~s}$ by adding data from the tomographic study of [3] and inverted using a non-linear procedure. As a result of the inversion process, a set of models of the Swave velocity vs. depth in the crust and upper mantle are found.

In six regions, we identify a typically oceanic crust and upper mantle structure, while in the other two the models are consistent with the presence of a continental structure. Two regions, located over the major geological zones of the accretionary crust of the Caribbean region, are characterized by a peculiar crust and upper mantle structure, indicating the presence of lithospheric roots reaching, at least, about $200 \mathrm{~km}$ of depth.
\end{abstract}




\section{Introduction}

The Caribbean region comprises the sea with the same name, an island arc and continental portions of Central and South America. This region is mainly characterized by oceanic crust with great heterogeneities that reveal its complex geology. There are important tectonic elements as the Cayman Trough (where a process of formation of oceanic crust is in progress), the Cayman Ridge and Gonave microplate, as well as zones with accretionary crust (where the North American plate is subducting the Caribbean one, and the Nazca and Cocos Plates are subducting the Caribbean and North American Plates). A detailed analysis of the geological and tectonic characteristics of this region can be found in [4].

Pioneering studies of the dispersion of group velocity of Rayleigh waves in the region that includes Caribbean, Central America, Central Western Atlantic Ocean and Northern part of South America were performed in the sixties [5-7], and in Cuba somewhat later [8].

In the last years, the existence of specific software, for data processing and inversion, and of broadband stations (BB) with digital recording in the area has increased the quality of the available dispersion measurements. In an earlier paper [9] the group velocity dispersion curves for the fundamental mode of Rayleigh waves was determined along several paths and inverted to obtain crustupper mantle models. The availability of data about the crust structure, summarized and generalized by several authors e.g. [4, 10], the most recent regional studies [3, 11-15] and global studies [16-18] allow us now to make a refined study of the region. For this purpose we perform Rayleigh waves group velocity tomography, considering relatively short paths (regional trajectories), we regionalize the dispersion curves locally obtained by the tomography and we invert them, into average regionalized structural models, with a non-linear inversion scheme.

\section{Data}

The primary selection of waveforms, to be used in the dispersion analysis, has been done in the World Data Center (IRIS) and in the archives of the Cuban National Seismological Service (SSSN) imposing the following criteria on the source properties:

Depth: $h<75 \mathrm{~km}$, Magnitude: $\mathrm{M}_{\mathrm{S}}>5.0$, Latitude (North): $0^{\circ}-35^{\circ}$, Longitude (West): $50^{\circ}-120^{\circ}$. As a result, 205 records, obtained in 13 broadband regional stations (Table 1), have been processed and the corresponding dispersion curves, in the period range from $10 \mathrm{~s}$ to $40 \mathrm{~s}$ [37], have been obtained (Table 2). The upper period limit is imposed by the technical characteristics of the BB stations of the Cuban National Seismological Service [19], which recorded the largest number of seismograms. The stations, epicenters and paths are shown in Fig. 1.

\section{The method}

\section{a) Determination of dispersion curves and tomographic maps.}

The dispersion curves of the fundamental mode of Rayleigh waves along each path are determined using the frequency-time analysis (FTAN), in its most updated version [1, 2]. The experimental errors of these measurements for each period range from 0.06 to $0.09 \mathrm{~km} / \mathrm{s}$ and are determined as the average between the differences of group velocity values for at least 5 pair of paths, where for each pair the station is the same and the distance between the epicenters is less than $0.3^{\circ}$.

For the tomographic analysis, the methodology described in [20-22] is applied to the dispersion curves and a set of seven tomographic maps for periods ranging from $10 \mathrm{~s}$ to $40 \mathrm{~s}$ at intervals of $5 \mathrm{~s}$ are obtained (Fig.2). The lateral resolution (a) determined by the coverage of paths is about $500 \mathrm{~km}$ in the Central-West Caribbean, the Antilles and the south of Central America (Fig.3); the azimuthal 
resolution $(\varepsilon)$ of the traces [22] indicates, in general, an adequate spatial distribution of paths for this region (Fig. 4). As could be expected, due to the inclusion of relatively more local dispersion paths, the lateral resolution we reach is higher than the one obtained by [3] for this area.

\section{b) Regionalization analysis of tomography results}

Considering their lateral resolution, the tomographic maps are discretized in cells of $2^{\circ} \times 2^{\circ}$, for which cellular dispersion curves are determined. A discrimination based on tomography resolution over the original $200\left(2^{\circ} \times 2^{\circ}\right)$ cells is done and only those cells belonging to the areas where the lateral resolution is $\leq 500 \mathrm{~km}$ have been selected. They essentially correspond to a region that comprises Central-Eastern Caribbean, Central America and the Northernmost part of Western Venezuela and Colombia. For each of the 81 selected cells, a group velocity dispersion curve is constructed. Their visual inspection evidences the presence of regions with an approximately similar dispersion.

To delimit such regions spatially, the grouping of the dispersion curves is performed using an extension of the non-supervised logical-combinatorial algorithms included in PROGNOSIS system $[23,24]$. The main characteristics of the algorithm are the following:

- Let the grid point number " $j$ " be the object " $O$ ". An object is described in terms of the variables " $x_{t}\left(O_{j}\right)$ ", $t=1, n$. In our case, the variables are the values of the group velocity at different periods.

- Let $\left.C_{t} \mid x_{t}\left(O_{i}\right), x_{t}\left(O_{j}\right)\right\rfloor$ be the distance between two objects for the variable " $x_{t}$ ", defined as:

$$
C_{t}\left[x_{t}\left(O_{i}\right), x_{t}\left(O_{j}\right)\right]=\left\{\begin{array}{ccc}
1 & \text { if } & \left|x_{t}\left(O_{\mathrm{i}}\right)-x_{t}\left(O_{j}\right)\right| \leq \varepsilon_{t} \\
0 & \text { elsewhere }
\end{array}\right.
$$

where $\varepsilon_{t}$ is the permitted difference between the values of the variable "t" (selected as the experimental error in the dispersion curves).

- Let $S\left(O_{i}, O_{j}\right)$ be the similarity function between objects $O_{i}$ and $O_{j}$. Two objects $O_{i}$ and $O_{j}$ are $\beta_{o}$ similar, if and only if $S\left(O_{i}, O_{j}\right) \geq \beta_{o}$, where $\beta_{o}$, the level of the classification, is between 0 and 1 . The similarity between objects is calculated by the formula:

$$
S\left(O_{i}, O_{j}\right)=\sum_{t=1}^{n} \mathrm{p}_{t} \cdot C_{t}\left[x_{t}\left(O_{i}\right), x_{t}\left(O_{j}\right)\right] / n \sum_{t=1}^{n} \mathrm{p}_{t}
$$

where $\mathrm{n}$ is the number of considered variables and $p_{t}$ is the "informative weight" of the variable " $\mathrm{t}$ " that may vary between 0 and 1 (selected equal to 0.7 for the period of $10 \mathrm{~s}$. and equal to 1 for all other periods).

- An object belongs to a compact set if the most $\beta_{o}$-similar to it belongs to this set too, or if it is the most similar to another object belonging to the set.

- The procedure starts by fixing the $\beta_{o}$-level, then the corresponding $\beta_{o}$-compact sets are determined. This process is made interactively using the procedure described by Pico [24].

The difference between the informative weight selected for the period $\mathrm{T}=10 \mathrm{~s}$ and the other periods, is due to the fact that this point of the dispersion curves is, in general, the most difficult to determine by FTAN analysis.

The classification of the 81 curves has been done with a similarity level $\beta_{o}=0.51$. As a result of the process, eight groups of dispersion curves are obtained (fig. 5), which allow us to perform the zoning of the studied region shown in fig.6. In the map there is an additional differentiation between regions 
with the same typical curve, but with significantly different, a priori known, properties, which require separate inversion.

\section{c) Determination of the S-wave velocities vs. depth models for the crust and the upper mantle}

We extend our dispersion relations to longer periods using the group velocity tomographic results of [3], ranging from $50 \mathrm{sec}$. to $150 \mathrm{sec}$ (Table 2). The associated experimental error at each period is determined as the square root of the sum of the square of the measurement error group velocity measurements and the standard deviation of the group velocity from the average value in the region (Table 2). The non-linear inversion method called "hedgehog" [25] has been applied to the average dispersion curves for each region. For each structural model, group velocity curves are computed and if, at each period, the difference between the computed and the experimental values is less than the measurement error, and if the r.m.s. value of the differences is less than a chosen fraction (usually about $60 \%$ ) of the average single point experimental error, $\rho_{\mathrm{g}}$, the model is accepted [26, 27].

The inverted parameters are the thickness of five layers and their Vs velocities (Table 3), with $\mathrm{Vp} / \mathrm{Vs}$ $=\sqrt{ } 3$. The density is fixed from its relation with $\mathrm{Vp}$, in rough agreement with the Nafe-Drake relation $[28,29]$. The parameterization of the input data and the determination of the appropriated step $\left(\Delta \mathrm{P}_{\mathrm{i}}\right)$ of each inverted parameter is made following the procedure described by [27], and using the code developed by [30] for the analytical determination of the partial derivatives of the dispersion relations with respect to the structural parameters.

A generalization from the available regional and global information is used to fix the parameters of the upper crust and sedimentary layers, while, for the water layers, bathymetric information from [31] is used. The structure deeper than $350 \mathrm{~km}$ is the same for all the considered cells and is defined accordingly with already published models, e.g. [17, 32].

For each region, to reduce the effects of the projection of possible systematic errors into the inverted structural model, the r.m.s. of the chosen solution is as close as possible to the average value of the r.m.s. of all solutions for the region. If more than one solution satisfies this "average r.m.s." criterion, among them, it is preferred the one in which the $\Delta \mathrm{P}_{\mathrm{i}}$ values are most frequently present (Table 4 ).

\section{Discussion}

The tomographic maps (fig. 2) evidence the geotectonic heterogeneity of the Caribbean region, as it was expected from a-priori knowledge [4, 15]. Both the tomographic maps and the structural models obtained as a result of the inversion indicate a predominance of oceanic-like crust, with evidences for other crustal types in some parts of the studied region.

Region 1 (figures 6 and 7), which comprises the Cayman Trough, evidences an oceanic type of crust with a Moho at a depth of about $15 \mathrm{~km}$. The upper mantle shear-wave velocity, in the range 4.15-4.3 $\mathrm{km} / \mathrm{s}$, points towards the presence of a young ocean [33-35]. This result is in very good agreement with the results of previous investigations based on different geophysical methods, e.g. [4, 36]. In region 5 (figures 6 and 7) that corresponds to part of the Colombian Basin and North of the Panama Deformed Belt, the crust is oceanic, the Moho depth being at about $18 \mathrm{~km}$ with an average Vs above about $3.6 \mathrm{~km} / \mathrm{s}$, typical of the lower crust. This crustal thickness, anomalously large for a standard oceanic crust, could be an indication of the presence of some kind of accretionary crust, mainly present in the Panama Deformed Belt [4]. The upper mantle velocity in the range 4.35-4.65 km/s suggests that here the ocean is older than in the Cayman Trough. In both oceanic regions a slight low velocity channel can be present in the mantle.

The regions $2 \mathrm{a}$ (comprised in the Southern Nicaraguan Rise) and $2 \mathrm{~b}$ (including parts of Venezuelan Basin and Beata Ridge; figures 6 and 7) are characterized by the same type of dispersion curve. In 
both cases a crust of oceanic type (thickened) is present, the Moho depth is in the range $20-30 \mathrm{~km}$, the upper mantle shear velocity can be as high as $4.7 \mathrm{~km} / \mathrm{s}$ and a low velocity channel in the mantle, starting at depths in the range $55-75 \mathrm{~km}$, suggests an aged oceanic crust [35]. In both regions two crustal layers are present, one of them, the thicker, with a velocity ranging from 3.45 to $3.65 \mathrm{~km} / \mathrm{s}$, the other in region 2a represents a thin upper crust layer and in region $2 \mathrm{~b}$ a thin crustal low velocity channel. The regions $6 \mathrm{a}, 6 \mathrm{~b}$ and $6 \mathrm{c}$ (figures 6 and 7 ) are located in geological provinces where mainly an accretionary crust is present [4].

In region 6a, coinciding with the Central American accretionary complex, and with part of the Chortis Block and Maya Block of Central America (the last two blocks have been previously identified as continental by [4]), the Moho depth is in the range $27-45 \mathrm{~km}$, while in regions $6 \mathrm{~b}$ and $6 \mathrm{c}$ it is in the range $22-33 \mathrm{~km}$. In region $6 \mathrm{~b}$, coinciding with the complex accretionary type of crust present in the Greater Antilles Deformed Belt, there is a low velocity channel in the crust, while the upper mantle properties are consistent with the presence of lithospheric roots, extending to depths of more than 200 $\mathrm{km}$. Region 6c, included in the South Caribbean-northern South America accretionary complexes [4], is characterized by a fairly deep low velocity channel in the mantle, indicating that the lithospheric roots may reach, here, about $200 \mathrm{~km}$ of depth. In the three regions two crustal layers are present. In regions $6 \mathrm{a}$ and $6 \mathrm{c}$, that contain the Cocos-Caribbean and South Caribbean subduction zones respectively, the Vs in the lower one is relatively high.

In region 3 (figures 6 and 7), which is contained in the Maya Block, the Moho has a depth in the range 29-44 km and points toward the presence of a (possibly thickened) continental type of crust. In region 4 (figures 6 and 7), in the eastern part of the Maya Block, the Moho is at a depth in the range 27.5-35.5 $\mathrm{km}$, in agreement with the presence of continental crust in this geological province. In both regions two well distinct, upper and lower crustal layers are identified and a wide low velocity channel in the mantle is present, starting at depths ranging from about $70 \mathrm{~km}$ to $100 \mathrm{~km}$, as it could be expected in a stable continental platform [35].

The Eastern Nicaraguan Rise comprises the region 7b (figures 6 and 7): the presence of a thickened oceanic type of crust is consistent with a Moho depth ranging from $19.5 \mathrm{~km}$ to $25.5 \mathrm{~km}$ and with the presence of a well developed low velocity channel in the upper mantle, while in region 7a (figures 6 and 7; Yucatan Basin, parts of Cayman Trough and Greater Antilles accretionary complex) the Moho depth is in the range $14.5-24.5 \mathrm{~km}$, with a lowest upper mantle velocity ranging from $4.0 \mathrm{~km} / \mathrm{s}$ to $4.15 \mathrm{~km} / \mathrm{s}$ and a high lower crust velocity $(3.75-3.95 \mathrm{~km} / \mathrm{s})$. The features shown in $7 \mathrm{a}$ are well consistent with previous results form seismic profiles studies [12].

Other curves, which were grouped as type 8 by the logical-combinatorial procedure, did not determine any specific region; therefore they have not been inverted.

\section{Conclusions}

1. The tomographic study of the group velocity of the fundamental mode of Rayleigh waves in the range from 10 to 40 seconds in the Central-West Caribbean improves our knowledge about the crust and upper mantle properties of this region, evidences its heterogeneity and the predominant presence of oceanic-like crust in the region.

2. Eleven regions have been identified on the base of the similarity of their group velocity dispersion properties. For each region the structure of the crust and upper mantle, as obtained by non-linear inversion of extended dispersion curves until $150 \mathrm{~s}$, is described by S-waves velocity vs. depth models. 
3. In the regions $1,2 \mathrm{a}, 2 \mathrm{~b}, 5,7 \mathrm{a}$ and $7 \mathrm{~b}$ the crust and upper mantle structure is of oceanic type, and indicate, in agreement with the average models of [33-35], the presence of oceans of different age [35]. A single layer oceanic crust is detected in all regions, with the exception of regions $2 \mathrm{a}$ and $2 \mathrm{~b}$ where an additional very thin layer is present.

4. The regions 3 and 4 have the properties of stable continental structures.

5. The regions $6 \mathrm{~b}$ and $6 \mathrm{c}$ are located over the major geological zones of the accretionary crust of the Caribbean region and are characterized by a peculiar crust and upper mantle structure, indicating the presence of lithospheric roots reaching, at least, about $200 \mathrm{~km}$ of depth.

\section{Acknowledgements}

The authors want to thank Anatoli L. Levshin from University of Colorado, for kindly providing us with the long period group velocities. They also recognize the help of Enrique Diego Arango Arias, from National Centre for Seismological Research of Cuba in the geological interpretation of the results, and Antonella Pontevivo from the Department of Earth Sciences of the University of Trieste, in the data processing. The present work is done with the financial support of the Associateship and TRIL Programs and SAND group of the "Abdus Salam" International Centre for Theoretical Physics, of the Ministry of Science, Technology and Environment of Cuba, as well as founded by the Italian MIUR Cofin-2001 (2001045878_007) and Cofin-2002 (2002047575_002).

\section{Bibliography}

1. Levshin, A.L., Pisarenko, V.F. and Pogrebinsky, G.A. (1972). “On a Frequency-Time Analysis of Oscillations", Ann. Geophys., 28(2), 211-218.

2. Levshin, A.L., Radnikova, L.I., and Berger, J. (1992), "Peculiarities of Surface Wave Propagation across Central Eurasia", Bull. Seismol. Soc. Am., 82, 2464-2493.

3. Vdovin, O., Rial, J.A., Levshin, A.L. and Ritzwoller, M. H. (1999). "Group-velocity Tomography of South America and the Surrounding Oceans”. Geophys. J. Int., 136, 324-340.

4. Dengo, G. and Case, J.E. (1990). "The Geology of North America. Volume H. The Caribbean Region”, The Geological Society of America, Boulder, U.S.A.

5. Papazachos, B.C. (1964). "Dispersion of Rayleigh Waves in the Gulf of Mexico and Caribbean Sea", Bull. Seis. Soc. America, 54(3), 909-926.

6. Santo, T. (1967). "Lateral Variation of Rayleigh Waves Dispersion Character. Part IV: The Gulf of Mexico and Caribbean Sea", Bull. Earthq. Res. Inst., 45(4), 963.

7. Tarr, A.C. (1969). "Rayleigh Waves Dispersion in the North Atlantic Ocean, Caribbean Sea and the Gulf of Mexico", J. Geophys. Res., 74(6), 1591.

8. Álvarez, L. (1977). "Dispersión de la velocidad de grupo de las ondas de Rayleigh en la región del Caribe", Informe Científico-Técnico No. 5, Instituto de Geofísica y Astronomía, La Habana, Cuba.

9. González, O., Álvarez, L., Panza, G.F. and Chimera, G. (2000). "Modelos de corteza de la región del Caribe a partir de la dispersión de ondas superficiales". In: Sismicidad de Cuba y estructura de la corteza en el Caribe, Editorial Academia, La Habana, Cuba, 45-56.

10. Van der Hilst, R. D. (1990): "Tomography with P, PP and pP Delay-time Data and the Threedimensional Mantle Structure below the Caribbean Region”, Ph.D. Thesis, University of Utrecht, Holand. 
11. Bassin, C., Laske, G. and Masters, G. (2000), "The Current Limits of Resolution for Surface Wave Tomography in North America", EOS Trans. AGU, 81, F897.

12. Chulick, G. S. and Mooney, W. D. (2002), "Seismic Structure of the Crust and Uppermost Mantle of North America and Adjacent Oceanic Basins: A Synthesis", Bull. Seism. Soc. Am., 92(6), 2478-2492.

13. Ligorría J.P. and Molina, E. (1997), "Crustal Velocity Structure of Southern Guatemala using Refracted and Sp Converted Waves", Geofísica Intern., 36(1).

14. Moreno, B., Grandison, M. and Atakan K. (2002). "Crustal Velocity Model along the Southern Cuban Margin: Implications for the Tectonic Regime at an Active Plate Boundary". Geophys. J. Int. 151, 632-645.

15. Pindell, J. and Kennan, L. (2001). "Kinematic Evolution of the Gulf of Mexico and Caribbean”. In: GCSSEPM Research Conference (Richard Fillon, ed.), Houston, U.S.A.

16. Laske, G. and Masters, G. (1997), "A Global Digital Map of Sediment Thickness", EOS Trans. AGU, 78, F483.

17. Montagner, J.P. and Kennet B.L.N. (1996) "How to Reconcile Body-wave and Normal-mode Reference Earth Models", Geophys.J.Int., 125, 229-248.

18. Mooney, W.D., Laske, G. and Masters, T.G. (1998). "CRUST 5.1: A Global Crustal Model at $5^{\circ}$ X 5", J. Geophys. Res., 103(B1), 727-747.

19. Zapata, J.A., Guasch, F., Serrano, M., Montenegro, C., Diez, E.R., González, O.F. and Del Pino, J. R. (2001), "Servicio Sismológico Nacional de Cuba: Primeros resultados después de la transformación tecnológica”. In: Red de estaciones e investigaciones sismológicas en Cuba, Editorial Academia, La Habana, Cuba, 27-34.

20. Ditmar, P.G. and Yanovskaya, T.B. (1987). "A Generalization of the Backus-Gilbert Method for Estimation of Lateral Variations of Surface Wave Velocity", Izv. Akad. Nauk SSSR, Fizika Zemli, (6), 30-60.

21. Yanovskaya, T.B. and Ditmar, P.G. (1990), "Smoothness Criteria in Surface Wave Tomography", Geophys. J. Int. 102, 63-72.

22. Yanovskaya, T.B. (1997), "Resolution Estimation in the Problems of Seismic Ray Tomography", Izvestiya, Physics of the Solid Earth, 33(9), 762-765.

23. Ruiz, J, Pico, R., López, R., Alaminos, C., Lazo, M., Baggiano, M., Barreto, E., Santana, A., Alvarez, L. and Chuy, T. (1992). "PROGNOSIS y sus aplicaciones a las geociencias". In: IBERAMIA-92, III Congreso Iberoamericano de Inteligencia Artificial, Memorias. México: LIMUSA, 561-586.

24. Pico, R. (1999). "Determinación del umbral de semejanza $\beta_{0}$ para los algoritmos de agrupamiento lógico-combinatorios, mediante el dendrograma de un algoritmo jerárquico". SIARP'99, IV Simposio Iberoamericano de Reconocimiento de Patrones. Memorias, 259-265.

25. Valyus, V.P. (1968), "Determining seismic profiles from a set of observations (in Russian)". Vychislitielnaya Seismologiya, 4, 3-14. English translation: Computational Seismology, ed. V.I. Keylis-Borok, Consultants Bureau, 1972, 114-118.

26. Biswas, N.N. and Knopoff, L. (1974). The Structure of the Upper Mantle under the U.S. from the Dispersion of Rayleigh Waves. Geophys. J. R. Astr. Soc., 36, 515-539.

27. Panza, G.F. (1981). "The Resolving Power of Seismic Surface Waves with Respect to Crust and Upper Mantle Structural Models". In: The Solution of the Inverse Problem in Geophysical Interpretation (Cassinis, R. ed.), Plenum Publishing Corporation, 39-77. 
28. Grant, F.S. and West G.F. (1965). "Interpretation Theory in Applied Geophysics", McGrawHill Inc., New York, U.S.A.

29. Fowler, C.M.R., 1995. "The Solid Earth. An introduction to Global Geophysics”. Cambridge Univ. Press.

30. Urban, L., Cichowicz, A. and Vaccari, F. (1993). "Computation of Analytical Partial Derivatives of Phase and Group Velocities of Rayleigh Waves Respect to Structural Parameters". Studia Geoph. Et Geod., 36, 14-36.

31. Smith, W.H.F. and Sandwell, D.T. (1997), "Global Sea Floor Topography from Satellite Altimetry and Ship Depth Soundings," Science Magazine, 277, issue 5334.

32. Du, Z.J., Michelini, A., and Panza, G.F. (1998). "EurID: a regionalised 3-D seismological model of Europe". Phys. Earth Planet. Inter., 105, 31-62.

33. Leeds A.R., Knopoff L. and Kausel E.G., 1974. "Variations of upper mantle structure under the Pacific Ocean". Science, 186, 141-143.

34. Forsyth, D. A., 1975: "The early structural evolution and anisotropy of the oceanic upper mantle". Geophys. J. R. astr. Soc., 43, 103-162.

35. Panza, G.F. (1980). "Evolution of the Earth's lithosphere. NATO Adv. Stud. Inst. Newcastle, 1979”. In: Mechanisms of Continental Drift and Plate Tectonics. Ed. by: P.A. Davies and S.K. Runcorn, Academic Press, 75-87.

36. Ten Brink, U.S., Coleman, D.F. and Dillon, W.P (2001). "Asymmetric Sea-floor Spreading, Crustal Thickness Variations and Transitional Crust in Cayman Trough from Gravity [abs.]", Geological Society of America, Abstracts with Programs, Annual Meeting, Boston, U.S.A, 33(6), A154.

37. Levshin, A.L., Ritzwoller, M.H., and Resovsky, J.S. (1999). "Source effects on surface wave travel times and group velocity maps.” Phys. Earth Planet. Inter., 115, 293-312. 
Table 1. Code, region, latitude, longitude and elevation of the stations, which have recorded the events selected for surface wave tomography. SSSN - Sistema del Servicio Sismológico Nacional (Cuba), GSN Global Seismic Network.

\begin{tabular}{|l|l|c|c|c|c|}
\hline Station code & Region & $\begin{array}{c}\text { Latitude } \\
\left({ }^{\circ} \mathrm{N}\right)\end{array}$ & $\begin{array}{c}\text { Longitude } \\
\left({ }^{\circ} \mathrm{W}\right)\end{array}$ & $\begin{array}{c}\text { Elevation } \\
(\mathrm{m})\end{array}$ & Network \\
\hline RCC & Río Carpintero & 19.9942 & -75.6958 & 100.0 & SSSN \\
\hline CCCC & Cascorro & 21.2000 & -77.7660 & 150.0 & SSSN \\
\hline LMGC & Las Mercedes & 20.0640 & -77.0050 & 220.0 & SSSN \\
\hline MOAC & Moa & 20.6600 & -74.9600 & 120.0 & SSSN \\
\hline MASC & Maisí & 20.1750 & -74.2310 & 320.0 & SSSN \\
\hline MGV & Manicaragua & 22.1100 & -79.9800 & 300.0 & SSSN \\
\hline SOR & Soroa & 22.7840 & -83.0080 & 206.0 & SSSN \\
\hline DWPF & Disney Wilderness Preserve & 28.1103 & -81.4328 & -142.4 & GSN \\
\hline HKT & Hockley & 29.9500 & -95.8333 & -415.0 & GSN \\
\hline SDV & Santo Domingo & 8.8861 & -70.6333 & 1580.0 & GSN \\
\hline TEIG & Tepich & 20.2263 & -88.2764 & 69.0 & GSN \\
\hline SJG & San Juan (Cayey) & 18.1117 & -66.1500 & -457.0 & GSN \\
\hline JTS & Juntas de Abangares & 10.2908 & -84.9525 & 340.0 & GSN \\
\hline
\end{tabular}


Table 2. Experimental data used in the non-linear inversion. For each region and period, group velocity $(\mathrm{U})$, single point error $\left(\rho_{\mathrm{g}}\right)$ and r.m.s. values are listed.

\begin{tabular}{|c|c|c|c|c|c|c|c|c|c|c|c|c|}
\hline & \multicolumn{2}{|c|}{ Region 1} & \multicolumn{2}{|c|}{ Region 2a } & \multicolumn{2}{|c|}{ Region $2 b$} & \multicolumn{2}{|c|}{ Region 3} & \multicolumn{2}{|c|}{ Region 4} & \multicolumn{2}{|c|}{ Region 5} \\
\hline $\begin{array}{c}\text { Period } \\
\text { (s) }\end{array}$ & $\begin{array}{c}\mathbf{U} \\
(\mathrm{km} / \mathrm{s})\end{array}$ & $\begin{array}{c}\rho_{\mathrm{g}} \\
(\mathrm{km} / \mathrm{s})\end{array}$ & $\begin{array}{c}\mathbf{U} \\
(\mathrm{km} / \mathrm{s})\end{array}$ & $\begin{array}{c}\rho_{\mathrm{g}} \\
(\mathrm{km} / \mathrm{s})\end{array}$ & $\begin{array}{c}\mathbf{U} \\
(\mathrm{km} / \mathrm{s})\end{array}$ & $\begin{array}{c}\rho_{\mathrm{g}} \\
(\mathrm{km} / \mathrm{s})\end{array}$ & $\begin{array}{c}\mathbf{U} \\
(\mathrm{km} / \mathrm{s})\end{array}$ & $\begin{array}{c}\rho_{\mathrm{g}} \\
(\mathrm{km} / \mathrm{s})\end{array}$ & $\begin{array}{c}\mathbf{U} \\
(\mathrm{km} / \mathrm{s})\end{array}$ & $\begin{array}{c}\rho_{\mathrm{g}} \\
(\mathbf{k m} / \mathbf{s})\end{array}$ & $\begin{array}{c}\mathrm{U} \\
(\mathrm{km} / \mathrm{s})\end{array}$ & $\begin{array}{c}\rho_{\mathrm{g}} \\
(\mathbf{k m} / \mathbf{s})\end{array}$ \\
\hline 10 & 2.79 & 0.16 & 2.27 & 0.17 & 2.30 & 0.09 & 2.08 & 0.14 & 2.65 & 0.12 & 2.42 & 0.15 \\
\hline 15 & 3.23 & 0.16 & 2.45 & 0.16 & 2.36 & 0.08 & 2.23 & 0.14 & 2.71 & 0.09 & 2.70 & 0.13 \\
\hline 20 & 3.45 & 0.09 & 3.11 & 0.08 & 2.98 & 0.08 & 2.55 & 0.14 & 2.94 & 0.07 & 3.26 & 0.07 \\
\hline 25 & 3.65 & 0.07 & 3.47 & 0.08 & 3.40 & 0.08 & 2.91 & 0.08 & 3.08 & 0.07 & 3.52 & 0.07 \\
\hline 30 & 3.71 & 0.08 & 3.63 & 0.08 & 3.66 & 0.08 & 3.24 & 0.07 & 3.32 & 0.06 & 3.68 & 0.09 \\
\hline 35 & 3.75 & 0.09 & 3.76 & 0.07 & 3.76 & 0.07 & 3.45 & 0.07 & 3.50 & 0.07 & 3.74 & 0.09 \\
\hline 40 & 3.78 & 0.09 & 3.86 & 0.07 & 3.85 & 0.07 & 3.59 & 0.07 & 3.66 & 0.08 & 3.81 & 0.09 \\
\hline 60 & 3.86 & 0.09 & 3.86 & 0.08 & 3.88 & 0.08 & 3.80 & 0.09 & 3.88 & 0.09 & 3.81 & 0.09 \\
\hline 80 & 3.88 & 0.09 & 3.86 & 0.09 & 3.84 & 0.09 & 3.81 & 0.10 & 3.89 & 0.09 & 3.83 & 0.09 \\
\hline 100 & 3.81 & 0.09 & 3.81 & 0.09 & 3.82 & 0.09 & 3.77 & 0.10 & 3.85 & 0.09 & 3.79 & 0.09 \\
\hline 125 & 3.73 & 0.09 & 3.74 & 0.09 & 3.77 & 0.09 & 3.74 & 0.10 & 3.83 & 0.09 & 3.73 & 0.09 \\
\hline 150 & 3.70 & 0.09 & 3.74 & 0.09 & 3.76 & 0.09 & 3.67 & 0.10 & 3.75 & 0.09 & 3.72 & 0.09 \\
\hline r.m.s. & & 0.06 & & 0.057 & & 0.049 & & 0.06 & & 0.050 & & 0.057 \\
\hline
\end{tabular}

\begin{tabular}{|c|c|c|c|c|c|c|c|c|c|c|}
\hline & \multicolumn{2}{|c|}{ Region 6a } & \multicolumn{2}{|c|}{ Region 6b } & \multicolumn{2}{|c|}{ Region 6c } & \multicolumn{2}{|c|}{ Region 7a } & \multicolumn{2}{|c|}{ Region 7b } \\
\hline $\begin{array}{l}\text { Period } \\
\text { (s) }\end{array}$ & $\begin{array}{c}\mathbf{U} \\
(\mathrm{km} / \mathrm{s})\end{array}$ & $\begin{array}{c}\rho_{\mathrm{g}} \\
(\mathrm{km} / \mathrm{s})\end{array}$ & $\begin{array}{c}\mathbf{U} \\
(\mathrm{km} / \mathrm{s})\end{array}$ & $\begin{array}{c}\rho_{\mathrm{g}} \\
(\mathrm{km} / \mathrm{s})\end{array}$ & $\begin{array}{c}\mathbf{U} \\
(\mathrm{km} / \mathrm{s})\end{array}$ & $\begin{array}{c}\rho_{\mathrm{g}} \\
(\mathrm{km} / \mathrm{s})\end{array}$ & $\begin{array}{c}\mathbf{U} \\
(\mathbf{k m} / \mathbf{s})\end{array}$ & $\begin{array}{c}\rho_{\mathrm{g}} \\
(\mathrm{km} / \mathrm{s})\end{array}$ & $\begin{array}{c}\mathbf{U} \\
(\mathrm{km} / \mathrm{s})\end{array}$ & $\begin{array}{c}\rho_{\mathrm{g}} \\
(\mathbf{k m} / \mathbf{s})\end{array}$ \\
\hline 10 & 2.24 & 0.16 & 2.52 & 0.11 & 2.27 & 0.09 & 2.58 & 0.19 & 2.68 & 0.15 \\
\hline 15 & 2.48 & 0.11 & 2.55 & 0.11 & 2.49 & 0.09 & 2.87 & 0.15 & 2.92 & 0.13 \\
\hline 20 & 2.80 & 0.09 & 2.86 & 0.09 & 2.94 & 0.07 & 3.14 & 0.10 & 3.12 & 0.10 \\
\hline 25 & 3.08 & 0.09 & 3.14 & 0.09 & 3.06 & 0.07 & 3.38 & 0.10 & 3.42 & 0.09 \\
\hline 30 & 3.28 & 0.09 & 3.39 & 0.09 & 3.22 & 0.08 & 3.52 & 0.10 & 3.60 & 0.08 \\
\hline 35 & 3.39 & 0.09 & 3.47 & 0.09 & 3.35 & 0.08 & 3.61 & 0.09 & 3.70 & 0.07 \\
\hline 40 & 3.46 & 0.09 & 3.54 & 0.09 & 3.45 & 0.09 & 3.69 & 0.09 & 3.73 & 0.08 \\
\hline 60 & 3.77 & 0.08 & 3.86 & 0.09 & 3.80 & 0.09 & 3.84 & 0.08 & 3.84 & 0.08 \\
\hline 80 & 3.78 & 0.09 & 3.82 & 0.09 & 3.83 & 0.09 & 3.89 & 0.09 & 3.86 & 0.09 \\
\hline 100 & 3.75 & 0.09 & 3.81 & 0.09 & 3.83 & 0.09 & 3.84 & 0.09 & 3.80 & 0.09 \\
\hline 125 & 3.70 & 0.09 & 3.77 & 0.09 & 3.79 & 0.09 & 3.78 & 0.09 & 3.72 & 0.09 \\
\hline 150 & 3.67 & 0.09 & 3.79 & 0.09 & 3.76 & 0.09 & 3.73 & 0.09 & 3.72 & 0.09 \\
\hline r.m.s. & & 0.058 & & 0.056 & & 0.051 & & 0.063 & & 0.057 \\
\hline
\end{tabular}


Table 3. Parameterization used in the non-linear inversion. Grey area: $\mathrm{h}$ (thickness), Vs and Vp of each layer The parameters of the uppermost layers are fixed on the base of available literature [e.g. 4, 12, 13, 14, $16,18,31]$. The variable parameters are $\mathrm{Pi}$, with $\mathrm{i}=1, \ldots 5$ for thickness and $\mathrm{i}=6, \ldots 10$ for $\mathrm{V}_{\mathrm{s}}$. White area: step $(\Delta \mathrm{Pi})$ and a priori allowed variability range for each parameter $\mathrm{Pi}$.

\begin{tabular}{|c|c|c|c|c|c|c|c|c|c|c|c|}
\hline \multicolumn{4}{|c|}{ Region 1} & \multicolumn{4}{|c|}{ Region 2a } & \multicolumn{4}{|c|}{ Region $2 \mathrm{~b}$} \\
\hline $\mathrm{h}$ & Vs & $\mathrm{Vp}$ & $\mathrm{d}$ & $\mathrm{h}$ & Vs & $\mathrm{Vp}$ & $\mathrm{d}$ & $\mathrm{h}$ & Vs & $\mathrm{Vp}$ & $\mathrm{d}$ \\
\hline$(\mathrm{km})$ & $(\mathrm{km} / \mathrm{s})$ & $(\mathrm{km} / \mathrm{s})$ & $\left(\mathrm{g} / \mathrm{cm}^{3}\right)$ & $(\mathrm{km})$ & $(\mathrm{km} / \mathrm{s})$ & $(\mathrm{km} / \mathrm{s})$ & $\left(\mathrm{g} / \mathrm{cm}^{3}\right)$ & $(\mathrm{km})$ & $(\mathrm{km} / \mathrm{s})$ & $(\mathrm{km} / \mathrm{s})$ & $\left(\mathrm{g} / \mathrm{cm}^{3}\right)$ \\
\hline 0.7 & 0 & 1.5 & 1.03 & 2.06 & 0 & 1.5 & 1.03 & 2.55 & 0 & 1.5 & 1.03 \\
\hline 0.5 & 0.72 & 2.07 & 1.98 & 1.0 & 0.64 & 2.0 & 1.95 & 0.7 & 0.64 & 2.0 & 1.95 \\
\hline 2.0 & 1.93 & 3.5 & 2.33 & 2.8 & 2.6 & 4.8 & 2.6 & 0.3 & 1.9 & 3.4 & 2.33 \\
\hline $\mathrm{P} 1$ & P6 & $\mathrm{P} 1 \times 1.73$ & 2.7 & $\mathrm{P} 1$ & P6 & $\mathrm{P} 1 \times 1.73$ & 2.7 & $\mathrm{P} 1$ & $\mathrm{P} 6$ & $\mathrm{P} 1 \times 1.73$ & 2.7 \\
\hline $\mathrm{P} 2$ & $\mathrm{P7}$ & $\mathrm{P} 2 \times 1.73$ & 2.9 & $\mathrm{P} 2$ & P7 & $\mathrm{P} 2 \times 1.73$ & 2.9 & $\mathrm{P} 2$ & $\mathrm{P} 7$ & $\mathrm{P} 2 \times 1.73$ & 2.9 \\
\hline P3 & $\mathrm{P} 8$ & $\mathrm{P} 3 \times 1.73$ & 3.0 & P3 & P8 & $\mathrm{P} 3 \times 1.73$ & 3.05 & P3 & $\mathrm{P} 8$ & $\mathrm{P} 3 \times 1.73$ & 3.05 \\
\hline $\mathrm{P} 4$ & P9 & $\mathrm{P} 4 \times 1.73$ & 3.1 & $\mathrm{P} 4$ & P9 & $\mathrm{P} 4 \times 1.73$ & 3.1 & $\mathrm{P} 4$ & P9 & $\mathrm{P} 4 \times 1.73$ & 3.1 \\
\hline P5 & $\mathrm{P} 10$ & $\mathrm{P} 5 \times 1.73$ & 3.3 & P5 & $\mathrm{P} 10$ & $\mathrm{P} 5 \times 1.73$ & 3.3 & P5 & $\mathrm{P} 10$ & $\mathrm{P} 5 \times 1.73$ & 3.3 \\
\hline $\mathrm{h}$ & Step & Range & & $\mathrm{h}$ & Step & Range & & $\mathrm{h}$ & Step & Range & \\
\hline$(\mathrm{km})$ & $(\mathrm{km})$ & $(\mathrm{km})$ & & $(\mathrm{km})$ & $(\mathrm{km})$ & $(\mathrm{km})$ & & $(\mathrm{km})$ & $(\mathrm{km})$ & $(\mathrm{km})$ & \\
\hline P1 & 6 & $8-26$ & & P1 & 4 & $5-25$ & & P1 & 5 & $5-35$ & \\
\hline $\mathrm{P} 2$ & 15 & $5-35$ & & $\mathrm{P} 2$ & 3 & $8-26$ & & $\mathrm{P} 2$ & 6 & $5-23$ & \\
\hline P3 & 20 & $10-50$ & & P3 & 24 & $4-52$ & & P3 & 16 & $8-56$ & \\
\hline $\mathrm{P} 4$ & 30 & $20-80$ & & $\mathrm{P} 4$ & 20 & $15-55$ & & $\mathrm{P} 4$ & 15 & $15-60$ & \\
\hline P5 & 40 & $40-160$ & & P5 & 60 & $30-150$ & & P5 & 30 & $60-120$ & \\
\hline $\mathrm{Vs}$ & Step & Range & & Vs & Step & Range & & Vs & Step & Range & \\
\hline$(\mathrm{km} / \mathrm{s})$ & $(\mathrm{km} / \mathrm{s})$ & $(\mathrm{km} / \mathrm{s})$ & & $(\mathrm{km} / \mathrm{s})$ & $(\mathrm{km} / \mathrm{s})$ & $(\mathrm{km} / \mathrm{s})$ & & $(\mathrm{km} / \mathrm{s})$ & $(\mathrm{km} / \mathrm{s})$ & $(\mathrm{km} / \mathrm{s})$ & \\
\hline P6 & 0.3 & $2.3-4.7$ & & P6 & 0.2 & $2.3-3.7$ & & P6 & 0.03 & $2.3-3.50$ & \\
\hline P7 & 0.3 & $3.7-4.3$ & & $\mathrm{P7}$ & 0.2 & $2.3-4.15$ & & $\mathrm{P7}$ & 0.1 & $3.25-4.15$ & \\
\hline P8 & 0.2 & $4.3-4.7$ & & P8 & 0.3 & $4.1-4.7$ & & P8 & 0.15 & $4.15-4.75$ & \\
\hline P9 & 0.25 & $4.25-4.75$ & & P9 & 0.2 & $4.3-4.7$ & & P9 & 0.2 & \begin{tabular}{|l|}
$4.3-4.7$ \\
\end{tabular} & \\
\hline $\mathrm{P} 10$ & 0.10 & $4.3-4.7$ & & $\mathrm{P} 10$ & 0.15 & $4.35-4.75$ & & $\mathrm{P} 10$ & 0.2 & 4.3-4.7 & \\
\hline
\end{tabular}


Table 3. (continued)

\begin{tabular}{|c|c|c|c|c|c|c|c|c|c|c|c|}
\hline \multicolumn{4}{|c|}{ Region 3} & \multicolumn{4}{|c|}{ Region 4} & \multicolumn{4}{|c|}{ Region 5} \\
\hline $\mathrm{h}$ & Vs & $\mathrm{Vp}$ & $\mathrm{d}$ & $\mathrm{h}$ & Vs & Vp & $\mathrm{d}$ & $\mathrm{h}$ & Vs & $\mathrm{Vp}$ & $\mathrm{d}$ \\
\hline$(\mathrm{km})$ & $(\mathrm{km} / \mathrm{s})$ & $(\mathrm{km} / \mathrm{s})$ & $\left(\mathrm{g} / \mathrm{cm}^{3}\right)$ & $(\mathrm{km})$ & $(\mathrm{km} / \mathrm{s})$ & $(\mathrm{km} / \mathrm{s})$ & $\left(\mathrm{g} / \mathrm{cm}^{3}\right)$ & $(\mathrm{km})$ & $(\mathrm{km} / \mathrm{s})$ & $(\mathrm{km} / \mathrm{s})$ & $\left(\mathrm{g} / \mathrm{cm}^{3}\right)$ \\
\hline 0.1 & 0 & 1.5 & 1.03 & 0.1 & 0 & 1.5 & 1.03 & 1.8 & 0 & 1.5 & 1.03 \\
\hline 1.5 & 0.92 & 2.25 & 2.02 & 0.4 & 1.2 & 2.4 & 2.1 & 1.4 & 0.9 & 2.36 & 1.96 \\
\hline 2.5 & 2.08 & 3.75 & 2.37 & 1.0 & 1.93 & 3.4 & 2.33 & 2.8 & 1.8 & 4.4 & 2.33 \\
\hline $\mathrm{P} 1$ & P6 & $\mathrm{P} 1 \times 1.73$ & 2.7 & $\mathrm{P} 1$ & $\mathrm{P} 6$ & $\mathrm{P} 1 \times 1.73$ & 2.7 & $\mathrm{P} 1$ & $\mathrm{P} 6$ & $\mathrm{P} 1 \times 1.73$ & 2.8 \\
\hline $\mathrm{P} 2$ & $\mathrm{P} 7$ & $\mathrm{P} 2 \times 1.73$ & 2.9 & $\mathrm{P} 2$ & P7 & $\mathrm{P} 2 \times 1.73$ & 2.9 & $\mathrm{P} 2$ & $\mathrm{P} 7$ & $\mathrm{P} 2 \times 1.73$ & 3.05 \\
\hline P3 & P8 & $\mathrm{P} 3 \times 1.73$ & 3.05 & P3 & $\mathrm{P} 8$ & $\mathrm{P} 3 \times 1.73$ & 3.05 & P3 & $\mathrm{P} 8$ & $\mathrm{P} 3 \times 1.73$ & 3.1 \\
\hline $\mathrm{P} 4$ & P9 & $\mathrm{P} 4 \times 1.73$ & 3.1 & $\mathrm{P} 4$ & P9 & $\mathrm{P} 4 \times 1.73$ & 3.1 & $\mathrm{P} 4$ & P9 & $\mathrm{P} 4 \times 1.73$ & 3.1 \\
\hline $\mathrm{P} 5$ & $\mathrm{P} 10$ & $\mathrm{P} 5 \times 1.73$ & 3.3 & $\mathrm{P} 5$ & $\mathrm{P} 10$ & $\mathrm{P} 5 \times 1.73$ & 3.3 & $\mathrm{P} 5$ & $\mathrm{P} 10$ & $\mathrm{P} 5 \times 1.73$ & 3.3 \\
\hline $\mathrm{h}$ & Step & Range & & $\mathrm{h}$ & Step & Range & & $\mathrm{h}$ & Step & Range & \\
\hline$(\mathrm{km})$ & $(\mathrm{km})$ & $(\mathrm{km})$ & & $(\mathrm{km})$ & $(\mathrm{km})$ & $(\mathrm{km})$ & & $(\mathrm{km})$ & $(\mathrm{km})$ & $(\mathrm{km})$ & \\
\hline P1 & 3 & $5-23$ & & P1 & 4 & $5-25$ & & P1 & 4 & $5-25$ & \\
\hline $\mathrm{P} 2$ & 12 & $6-42$ & & $\mathrm{P} 2$ & 4 & $5-25$ & & $\mathrm{P} 2$ & 20 & $10-30$ & \\
\hline P3 & 10 & $11-31$ & & $\mathrm{P} 3$ & 5 & $7-32$ & & $\mathrm{P} 3$ & 20 & $10-50$ & \\
\hline P4 & 15 & $15-30$ & & $\mathrm{P} 4$ & 20 & $5-45$ & & $\mathrm{P} 4$ & 25 & $15-65$ & \\
\hline P5 & 30 & 60-120 & & P5 & 30 & $60-150$ & & P5 & 60 & $60-120$ & \\
\hline $\mathrm{Vs}$ & Step & Range & & Vs & Step & Range & & Vs & Step & Range & \\
\hline$(\mathrm{km} / \mathrm{s})$ & $(\mathrm{km} / \mathrm{s})$ & $(\mathrm{km} / \mathrm{s})$ & & $(\mathrm{km} / \mathrm{s})$ & $(\mathrm{km} / \mathrm{s})$ & $(\mathrm{km} / \mathrm{s})$ & & $(\mathrm{km} / \mathrm{s})$ & $(\mathrm{km} / \mathrm{s})$ & $(\mathrm{km} / \mathrm{s})$ & \\
\hline P6 & 0.1 & $2.3-3.7$ & & P6 & 0.2 & $2.3-4.7$ & & P6 & 0.1 & $2.3-4.3$ & \\
\hline $\mathrm{P} 7$ & 0.2 & $3.7-4.1$ & & P7 & 0.2 & $2.3-4.7$ & & $\mathrm{P} 7$ & 0.3 & $4.2-4.8$ & \\
\hline P8 & 0.2 & $4.1-4.7$ & & P8 & 0.2 & $4.3-4.7$ & & P8 & 0.15 & $4.25-4.7$ & \\
\hline P9 & 0.2 & $4.3-4.7$ & & P9 & 0.2 & $4.25-4.85$ & & P9 & 0.25 & $4.25-4.75$ & \\
\hline $\mathrm{P} 10$ & 0.2 & $4.3-4.7$ & & $\mathrm{P} 10$ & 0.2 & \begin{tabular}{|l|}
$4.3-4.7$ \\
\end{tabular} & & $\mathrm{P} 10$ & 0.25 & $4.25-4.75$ & \\
\hline
\end{tabular}


Table 3. (continued)

\begin{tabular}{|c|c|c|c|c|c|c|c|c|c|c|c|}
\hline \multicolumn{4}{|c|}{ Region 6a } & \multicolumn{4}{|c|}{ Region 6b } & \multicolumn{4}{|c|}{ Region 6c } \\
\hline $\mathrm{h}$ & Vs & Vp & $\mathrm{d}$ & $\mathrm{h}$ & Vs & $\mathrm{Vp}$ & $\mathrm{d}$ & $\mathrm{h}$ & Vs & $\mathrm{Vp}$ & $\mathrm{d}$ \\
\hline$(\mathrm{km})$ & $(\mathrm{km} / \mathrm{s})$ & $(\mathrm{km} / \mathrm{s})$ & $\left(\mathrm{g} / \mathrm{cm}^{3}\right)$ & $(\mathrm{km})$ & $(\mathrm{km} / \mathrm{s})$ & $(\mathrm{km} / \mathrm{s})$ & $\left(\mathrm{g} / \mathrm{cm}^{3}\right)$ & $(\mathrm{km})$ & $(\mathrm{km} / \mathrm{s})$ & $(\mathrm{km} / \mathrm{s})$ & $\left(\mathrm{g} / \mathrm{cm}^{3}\right)$ \\
\hline 0.6 & 1.0 & 2.4 & 2.05 & 1.6 & 0 & 1.5 & 1.03 & 0.9 & 1.09 & 2.4 & 2.08 \\
\hline 0.6 & 1.2 & 2.5 & 2.1 & 0.6 & 0.84 & 2.05 & 1.97 & 1.5 & 2.18 & 3.95 & 2.18 \\
\hline 5.0 & 3.0 & 5.19 & 2.5 & 2.4 & 1.93 & 3.45 & 2.33 & 4.0 & 3.0 & 5.19 & 2.5 \\
\hline $\mathrm{P} 1$ & P6 & $\mathrm{P} 1 \times 1.73$ & 2.7 & $\mathrm{P} 1$ & $\mathrm{P} 6$ & $\mathrm{P} 1 \times 1.73$ & 2.7 & $\mathrm{P} 1$ & $\mathrm{P} 6$ & $\mathrm{P} 1 \times 1.73$ & 2.6 \\
\hline $\mathrm{P} 2$ & $\mathrm{P} 7$ & $\mathrm{P} 2 \times 1.73$ & 2.9 & $\mathrm{P} 2$ & P7 & $\mathrm{P} 2 \times 1.73$ & 2.9 & $\mathrm{P} 2$ & $\mathrm{P} 7$ & $\mathrm{P} 2 \times 1.73$ & 2.9 \\
\hline P3 & P8 & $\mathrm{P} 3 \times 1.73$ & 3.05 & P3 & $\mathrm{P} 8$ & $\mathrm{P} 3 \times 1.73$ & 2.95 & $\mathrm{P} 3$ & $\mathrm{P} 8$ & $\mathrm{P} 3 \times 1.73$ & 2.95 \\
\hline $\mathrm{P} 4$ & P9 & $\mathrm{P} 4 \times 1.73$ & 3.1 & $\mathrm{P} 4$ & P9 & $\mathrm{P} 4 \times 1.73$ & 3.1 & $\mathrm{P} 4$ & P9 & $\mathrm{P} 4 \times 1.73$ & 3.1 \\
\hline $\mathrm{P} 5$ & $\mathrm{P} 10$ & $\mathrm{P} 5 \times 1.73$ & 3.3 & $\mathrm{P} 5$ & $\mathrm{P} 10$ & $\mathrm{P} 5 \times 1.73$ & 3.3 & $\mathrm{P} 5$ & $\mathrm{P} 10$ & $\mathrm{P} 5 \times 1.73$ & 3.3 \\
\hline $\mathrm{h}$ & Step & Range & & $\mathrm{h}$ & Step & Range & & $\mathrm{h}$ & Step & Range & \\
\hline$(\mathrm{km})$ & $(\mathrm{km})$ & $(\mathrm{km})$ & & $(\mathrm{km})$ & $(\mathrm{km})$ & $(\mathrm{km})$ & & $(\mathrm{km})$ & $(\mathrm{km})$ & $(\mathrm{km})$ & \\
\hline P1 & 4 & 6-18 & & P1 & 8 & $6-22$ & & P1 & 3 & $5-23$ & \\
\hline $\mathrm{P} 2$ & 15 & $5-35$ & & $\mathrm{P} 2$ & 6 & $7-31$ & & $\mathrm{P} 2$ & 10 & $10-40$ & \\
\hline P3 & 30 & $22-82$ & & P3 & 20 & $3.5-43.5$ & & P3 & 15 & $10-55$ & \\
\hline $\mathrm{P} 4$ & 50 & $27.5-77.5$ & & $\mathrm{P} 4$ & 30 & $17.5-77.5$ & & $\mathrm{P} 4$ & 20 & $17.5-57.5$ & \\
\hline P5 & 50 & 30-130 & & P5 & 45 & $60-150$ & & P5 & 40 & 40-120 & \\
\hline Vs & Step & Range & & Vs & Step & Range & & $\mathrm{Vs}$ & Step & Range & \\
\hline$(\mathrm{km} / \mathrm{s})$ & $(\mathrm{km} / \mathrm{s})$ & $(\mathrm{km} / \mathrm{s})$ & & $(\mathrm{km} / \mathrm{s})$ & $(\mathrm{km} / \mathrm{s})$ & $(\mathrm{km} / \mathrm{s})$ & & $(\mathrm{km} / \mathrm{s})$ & $(\mathrm{km} / \mathrm{s})$ & $(\mathrm{km} / \mathrm{s})$ & \\
\hline P6 & 0.1 & $3.0-4.7$ & & P6 & 0.1 & $2.35-3.75$ & & P6 & 0.2 & $3.0-3.4$ & \\
\hline $\mathrm{P} 7$ & 0.3 & $3.15-4.35$ & & P7 & 0.2 & $3.15-3.95$ & & $\mathrm{P} 7$ & 0.3 & $3.15-4.65$ & \\
\hline P8 & 0.2 & \begin{tabular}{|l|}
$4.3-4.7$ \\
\end{tabular} & & P8 & 0.3 & \begin{tabular}{|l|}
$3.9-4.5$ \\
\end{tabular} & & P8 & 0.2 & \begin{tabular}{|l|}
$4.3-4.7$ \\
\end{tabular} & \\
\hline P9 & 0.2 & $4.3-4.7$ & & P9 & 0.2 & $4.3-4.7$ & & P9 & 0.2 & $4.3-4.7$ & \\
\hline $\mathrm{P} 10$ & 0.2 & $4.3-4.7$ & & $\mathrm{P} 10$ & 0.1 & 4.3-4.7 & & $\mathrm{P} 10$ & 0.2 & $4.3-4.7$ & \\
\hline
\end{tabular}


Table 3. (continued)

\begin{tabular}{|c|c|c|c||c|c|c|c||}
\hline \hline \multicolumn{5}{|c||}{ Region 7a } & \multicolumn{4}{c||}{ Region 7b } \\
\hline \hline $\mathrm{h}$ & $\mathrm{Vs}$ & $\mathrm{Vp}$ & $\mathrm{d}$ & $\mathrm{h}$ & $\mathrm{Vs}$ & $\mathrm{Vp}$ & $\mathrm{d}$ \\
\hline$(\mathrm{km})$ & $(\mathrm{km} / \mathrm{s})$ & $(\mathrm{km} / \mathrm{s})$ & $\left(\mathrm{g} / \mathrm{cm}^{3}\right)$ & $(\mathrm{km})$ & $(\mathrm{km} / \mathrm{s})$ & $(\mathrm{km} / \mathrm{s})$ & $\left(\mathrm{g} / \mathrm{cm}^{3}\right)$ \\
\hline 2.5 & 0 & 1.5 & 1.03 & 1.2 & 0 & 1.5 & 1.03 \\
\hline 0.7 & 1.1 & 2.3 & 2.3 & 1.3 & 0.84 & 3.1 & 1.95 \\
\hline 1.3 & 2.7 & 5.1 & 2.7 & 3.0 & 2.4 & 5.5 & 2.5 \\
\hline P1 & P6 & P1x1.73 & 2.8 & P1 & P6 & P1x1.73 & 2.7 \\
\hline P2 & P7 & P2x1.73 & 2.9 & P2 & P7 & P2x1.73 & 2.9 \\
\hline P3 & P8 & P3x1.73 & 3.0 & P3 & P8 & P3x1.73 & 3.0 \\
\hline P4 & P9 & P4x1.73 & 3.1 & P4 & P9 & P4x1.73 & 3.1 \\
\hline P5 & P10 & P5x1.73 & 3.3 & P5 & P10 & P5x1.73 & 3.3 \\
\hline \hline h & Step & Range & & h & Step & Range & \\
\hline (km) & $(\mathrm{km})$ & $(\mathrm{km})$ & & $(\mathrm{km})$ & $(\mathrm{km})$ & $(\mathrm{km})$ & \\
\hline P1 & 10 & $5-35$ & & P1 & 6 & $11-35$ & \\
\hline P2 & 15 & $15-45$ & & P2 & 10 & $15-35$ & \\
\hline P3 & 30 & $15-45$ & & P3 & 40 & $15-55$ & \\
\hline P4 & 40 & $25-65$ & & P4 & 40 & $15-55$ & \\
\hline P5 & 60 & $60-120$ & & P5 & 60 & $30-150$ & \\
\hline \hline Vs & Step & Range & & Vs & Step & Range & \\
\hline (km/s) & $(\mathrm{km} / \mathrm{s})$ & $(\mathrm{km} / \mathrm{s})$ & & $(\mathrm{km} / \mathrm{s})$ & $(\mathrm{km} / \mathrm{s})$ & $(\mathrm{km} / \mathrm{s})$ & \\
\hline P6 & 0.2 & $2.45-4.25$ & & P6 & 0.15 & $2.35-4.3$ & \\
\hline P7 & 0.3 & $4.0-4.6$ & & P7 & 0.2 & $4.0-4.6$ & \\
\hline P8 & 0.2 & $4.3-4.7$ & & P8 & 0.2 & $4.3-4.7$ & \\
\hline P9 & 0.2 & $4.3-4.7$ & & P9 & 0.2 & $4.3-4.7$ & \\
\hline P10 & 0.2 & $4.3-4.7$ & & P10 & 0.2 & $4.3-4.7$ & \\
\hline & & & & & & & \\
\hline \hline
\end{tabular}


Table 4. Range of variability of the parameters $\mathrm{h}$ (thickness) and Vs for each layer of the chosen solution. (Grey area evidences fixed parameters). In the table the values of the inverted parameters are rounded off to $0.5 \mathrm{~km}$ or to $0.05 \mathrm{~km} / \mathrm{s}$. We take into account the a priori information used to constrain the inversion, therefore, for each parameter, the chosen value does not necessarily fall in the centre of the variability range that can turn out to be smaller than the step, $\Delta \mathrm{Pi}$, used in the inversion. The thickness marked by * is not a truly inverted parameter, but it satisfies the condition that the total thickness from the free surface to the top of the fixed upper mantle is equal to a predefined quantity $\mathrm{H}$. In this study $\mathrm{H}=350 \mathrm{~km}$. The structure deeper than $\mathrm{H}$ is the same for all the considered cells and it has been fixed accordingly with already published models $[17,32]$.

\begin{tabular}{||c|c||c|c||c|c||c|c||}
\hline \multicolumn{2}{|c||}{ Region 1 } & \multicolumn{2}{c||}{ Region 2a } & \multicolumn{2}{c||}{ Region 2b } & \multicolumn{2}{c||}{ Region 3 } \\
\hline \hline $\begin{array}{c}\mathrm{h} \\
(\mathrm{km})\end{array}$ & $\begin{array}{c}\mathrm{Vs} \\
(\mathrm{km} / \mathrm{s})\end{array}$ & $\begin{array}{c}\mathrm{h} \\
(\mathrm{km})\end{array}$ & $\begin{array}{c}\mathrm{Vs} \\
(\mathrm{km} / \mathrm{s})\end{array}$ & $\begin{array}{c}\mathrm{h} \\
(\mathrm{km})\end{array}$ & $\begin{array}{c}\mathrm{Vs} \\
(\mathrm{km} / \mathrm{s})\end{array}$ & $\begin{array}{c}\mathrm{h} \\
(\mathrm{km})\end{array}$ & $\begin{array}{c}\mathrm{Vs} \\
(\mathrm{km} / \mathrm{s})\end{array}$ \\
\hline \hline 0.7 & 0 & 2.06 & 0 & 2.55 & 0 & 0.1 & 0 \\
\hline 0.5 & 0.72 & 1.0 & 0.64 & 0.7 & 0.64 & 1.5 & 0.92 \\
\hline 2.0 & 1.93 & 2.8 & 2.6 & 0.3 & 1.9 & 2.5 & 2.08 \\
\hline $11-17$ & $3.75-4.05$ & $5-7$ & $3.3-3.5$ & $12.5-17.5$ & $3.45-3.5$ & $12.5-15.5$ & $3.25-3.35$ \\
\hline $12.5-27.5$ & $4.15-4.3$ & $9.5-12.5$ & $3.45-3.65$ & $5-8$ & $3.2-3.3$ & $12-24$ & $3.8-4.0$ \\
\hline $40-50$ & $4.4-4.6$ & $40-52$ & $4.55-4.7$ & $32-48$ & $4.65-4.75$ & $26-31$ & $4.6-4.7$ \\
\hline $20-35$ & $4.25-4.40$ & $45-55$ & $4.4-4.6$ & $37.5-52.5$ & $4.4-4.6$ & $15-22.5$ & $4.6-4.7$ \\
\hline $140-160$ & $4.45-4.55$ & $120-150$ & $4.45-4.6$ & $105-120$ & $4.4-4.6$ & $105-120$ & $4.3-4.4$ \\
\hline$*$ & 4.75 & $*$ & 4.75 & $*$ & 4.75 & $*$ & 4.75 \\
\hline 67 & 4.9 & 67 & 4.9 & 67 & 4.9 & 67 & 4.9 \\
\hline \hline
\end{tabular}

\begin{tabular}{||c|c||c|c||c|c||c|c||}
\hline \hline \multicolumn{2}{|c||}{ Region 4 } & \multicolumn{2}{c||}{ Region 5 } & \multicolumn{2}{c||}{ Region 6a } & \multicolumn{2}{c||}{ Region 6b } \\
\hline \hline $\begin{array}{c}\mathrm{h} \\
(\mathrm{km})\end{array}$ & $\begin{array}{c}\mathrm{Vs} \\
(\mathrm{km} / \mathrm{s})\end{array}$ & $\begin{array}{c}\mathrm{h} \\
(\mathrm{km})\end{array}$ & $\begin{array}{c}\mathrm{Vs} \\
(\mathrm{km} / \mathrm{s})\end{array}$ & $\begin{array}{c}\mathrm{h} \\
(\mathrm{km})\end{array}$ & $\begin{array}{c}\mathrm{Vs} \\
(\mathrm{km} / \mathrm{s})\end{array}$ & $\begin{array}{c}\mathrm{h} \\
(\mathrm{km})\end{array}$ & $\begin{array}{c}\mathrm{Vs} \\
(\mathrm{km} / \mathrm{s})\end{array}$ \\
\hline \hline 0.1 & 0 & 1.8 & 0 & 0.6 & 1.0 & 1.6 & 0 \\
\hline 0.4 & 1.2 & 1.4 & 0.9 & 0.6 & 1.2 & 0.6 & 0.84 \\
\hline 1.0 & 1.93 & 2.8 & 1.8 & 5.0 & 3.0 & 2.4 & 1.93 \\
\hline $11-15$ & $3.2-3.4$ & $11-15$ & $3.65-3.75$ & $8-12$ & $3.05-3.15$ & $10-18$ & $3.6-3.7$ \\
\hline $15-19$ & $3.7-3.9$ & $10-20$ & $4.35-4.65$ & $12.5-27.5$ & $3.9-4.2$ & $7-10$ & $3.25-3.45$ \\
\hline $15-20$ & $4.3-4.4$ & $40-50$ & $4.5-4.65$ & $67-82$ & $4.4-4.6$ & $13.5-33.5$ & $4.35-4.5$ \\
\hline $35-45$ & $4.55-4.75$ & $52.5-65$ & $4.4-4.65$ & $52.5-77.5$ & $4.6-4.7$ & $62.5-77.5$ & $4.4-4.6$ \\
\hline $135-150$ & $4.4-4.6$ & $90-120$ & $4.4-4.65$ & $55-105$ & $4.3-4.4$ & $127.5-150$ & $4.55-4.65$ \\
\hline$*$ & 4.75 & $*$ & 4.75 & $*$ & 4.75 & $*$ & 4.75 \\
\hline 67 & 4.9 & 67 & 4.9 & 67 & 4.9 & 67 & 4.9 \\
\hline
\end{tabular}


Table 4. (continued)

\begin{tabular}{||c|c||c|c||c|c||}
\hline \hline \multicolumn{2}{||c||}{ Region 6c } & \multicolumn{2}{c||}{ Region 7a } & \multicolumn{2}{c||}{ Region 7b } \\
\hline \hline $\begin{array}{c}\mathrm{h} \\
(\mathrm{km})\end{array}$ & $\begin{array}{c}\mathrm{Vs} \\
(\mathrm{km} / \mathrm{s})\end{array}$ & $\begin{array}{c}\mathrm{h} \\
(\mathrm{km})\end{array}$ & $\begin{array}{c}\mathrm{Vs} \\
(\mathrm{km} / \mathrm{s})\end{array}$ & $\begin{array}{c}\mathrm{h} \\
(\mathrm{km})\end{array}$ & $\begin{array}{c}\mathrm{Vs} \\
(\mathrm{km} / \mathrm{s})\end{array}$ \\
\hline \hline 0.9 & 1.09 & 2.5 & 0 & 1.2 & 0 \\
\hline 1.5 & 2.18 & 0.7 & 1.1 & 1.3 & 0.84 \\
\hline 4.0 & 3.0 & 1.3 & 2.7 & 3.0 & 2.4 \\
\hline $6.5-9.5$ & $3.1-3.3$ & $10-20$ & $3.75-3.95$ & $14-20$ & $3.65-3.8$ \\
\hline $10-15$ & $3.6-3.9$ & $15-22.5$ & $4.0-4.15$ & $15-20$ & $4.3-4.5$ \\
\hline $32.5-47.5$ & $4.3-4.4$ & $30-45$ & $4.4-4.6$ & $35-55$ & $4.4-4.6$ \\
\hline $47.5-57.5$ & $4.6-4.7$ & $45-65$ & $4.4-4.6$ & $15-35$ & $4.6-4.7$ \\
\hline $60-100$ & $4.3-4.4$ & $60-90$ & $4.3-4.4$ & $60-120$ & $4.3-4.4$ \\
\hline$*$ & 4.75 & $*$ & 4.75 & $*$ & 4.75 \\
\hline 67 & 4.9 & 67 & 4.9 & 67 & 4.9 \\
\hline \hline
\end{tabular}




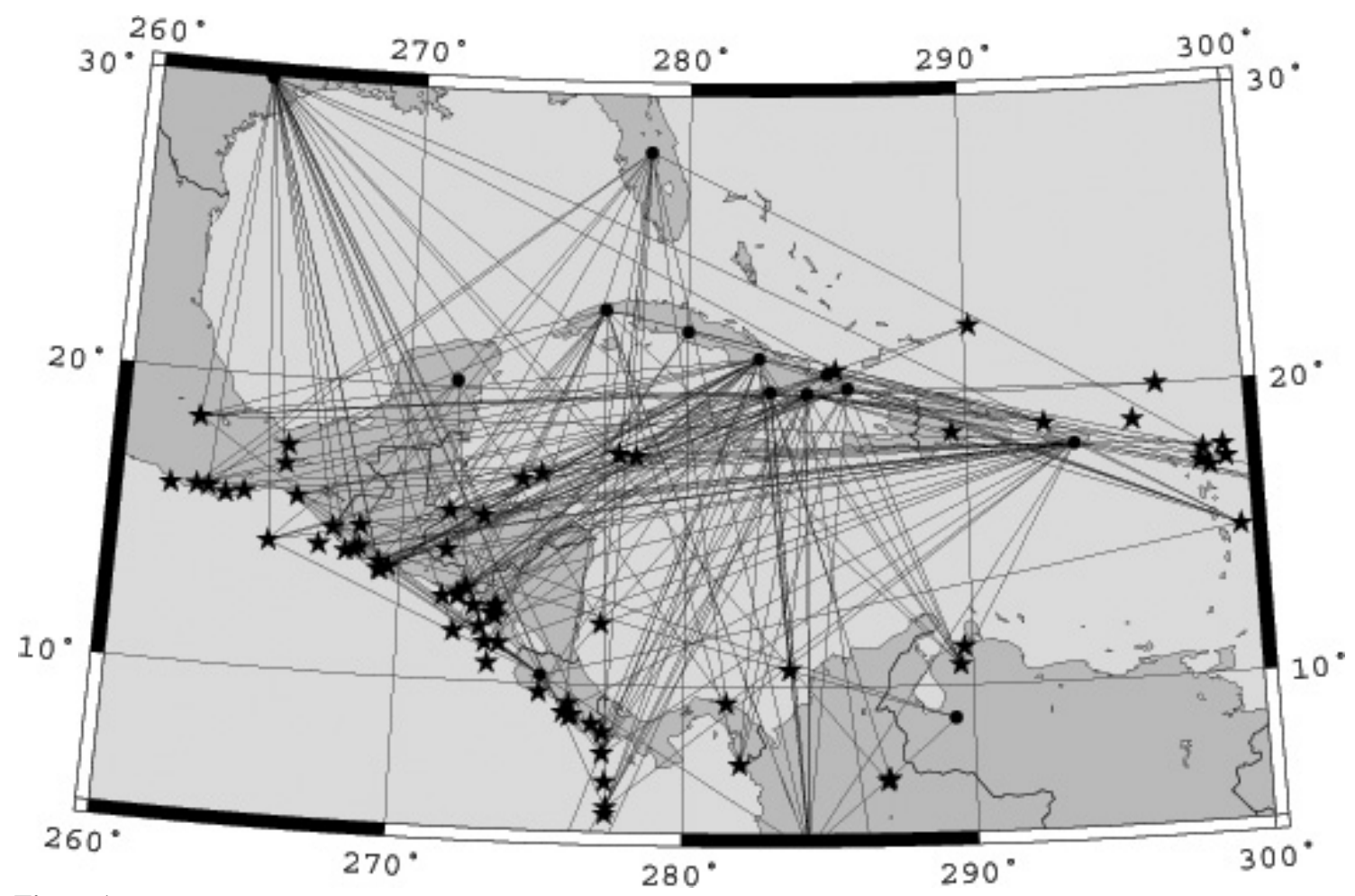

Figure1.

Epicenters (stars), stations (black points) and seismic paths selected for surface wave tomography. 

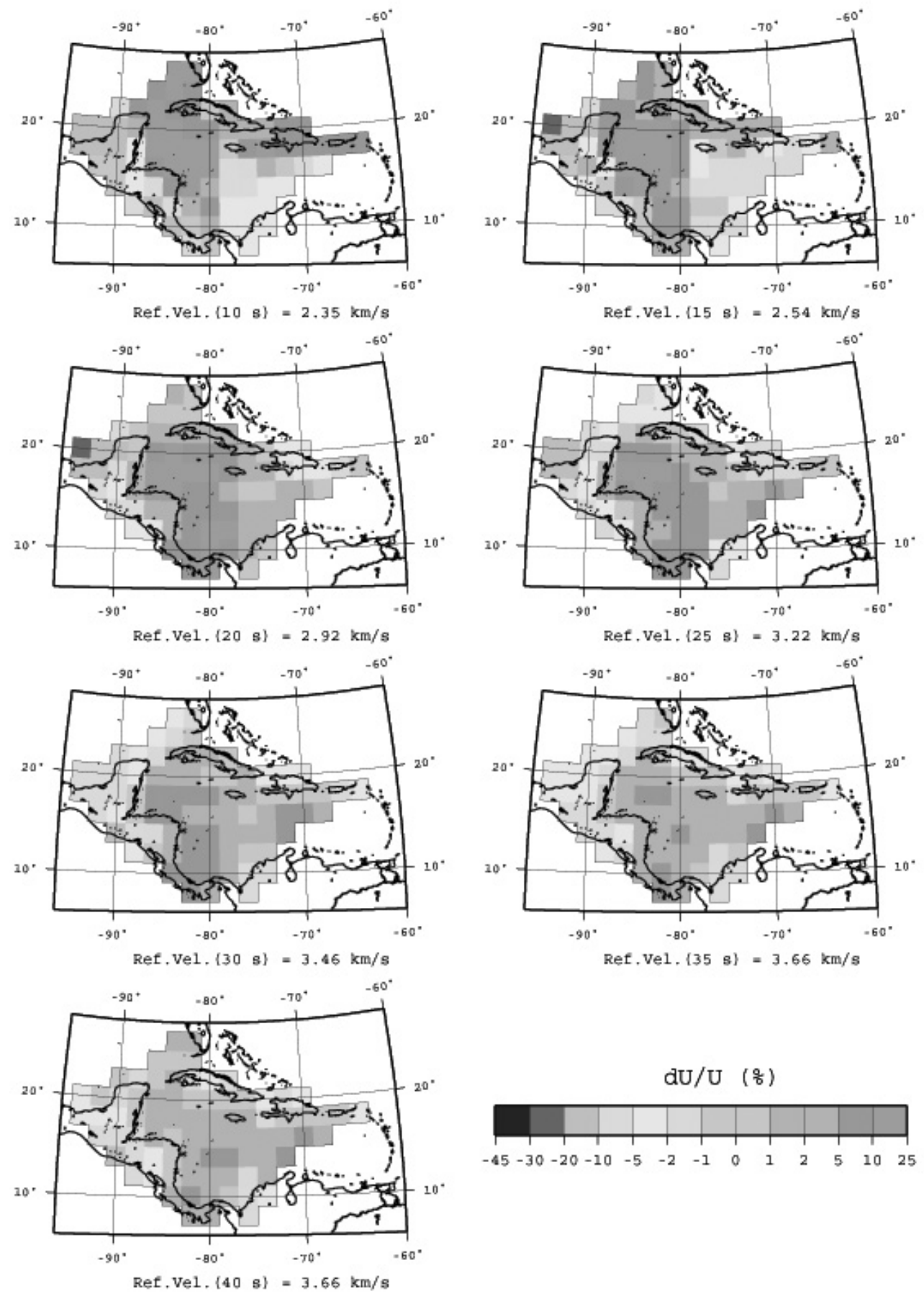

Figure 2.

Rayleigh waves group velocity tomography at different periods (10-40 s) shown as percent deviation from the average reference velocity (Ref. Vel.). 

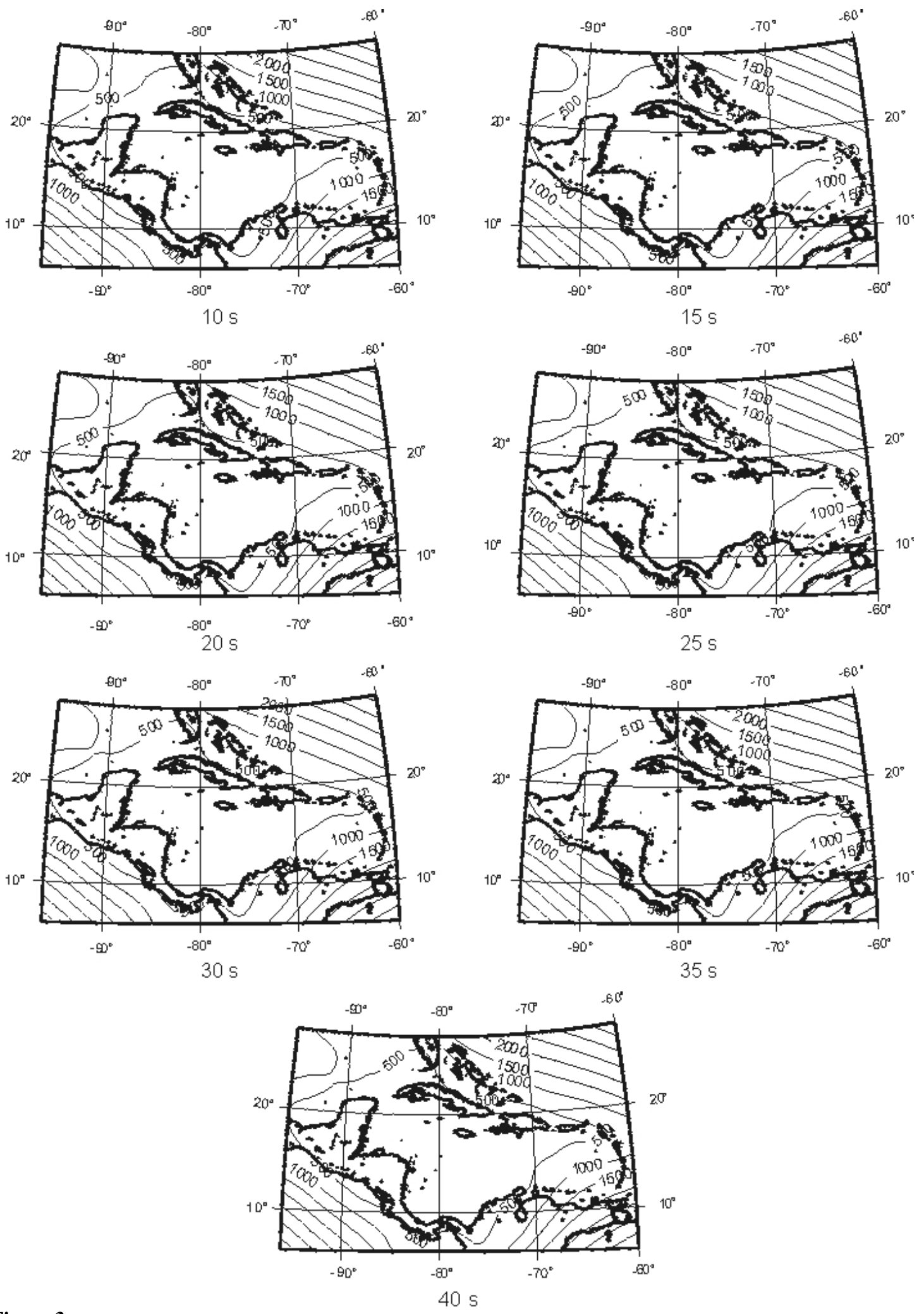

Figure 3.

Maps of "a" the horizontal resolution $(\mathrm{km})$ at different periods (10-40 s). 

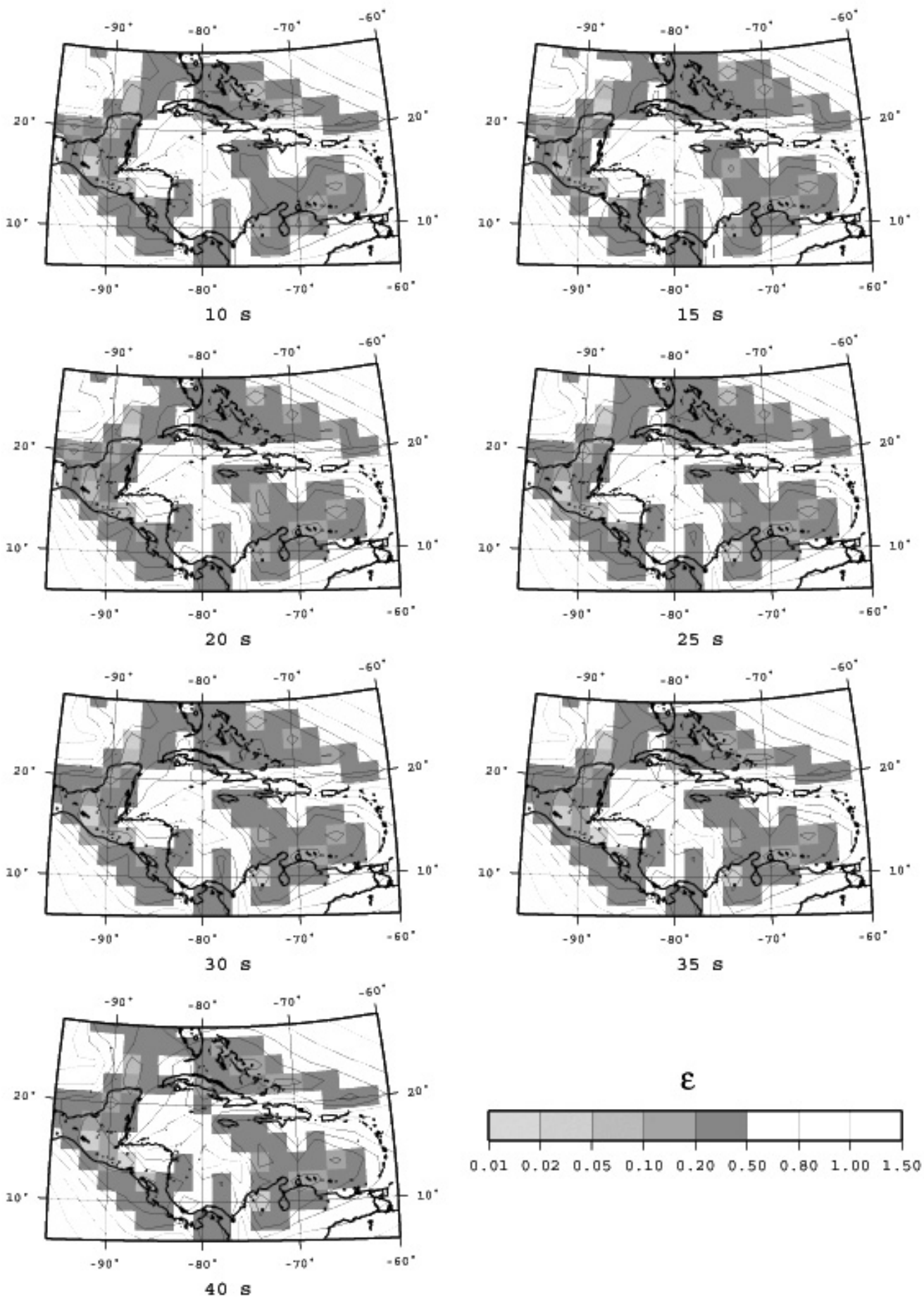

Figure 4.

Maps of the azimuthal resolution $\varepsilon$ at different periods (10-40 s). 

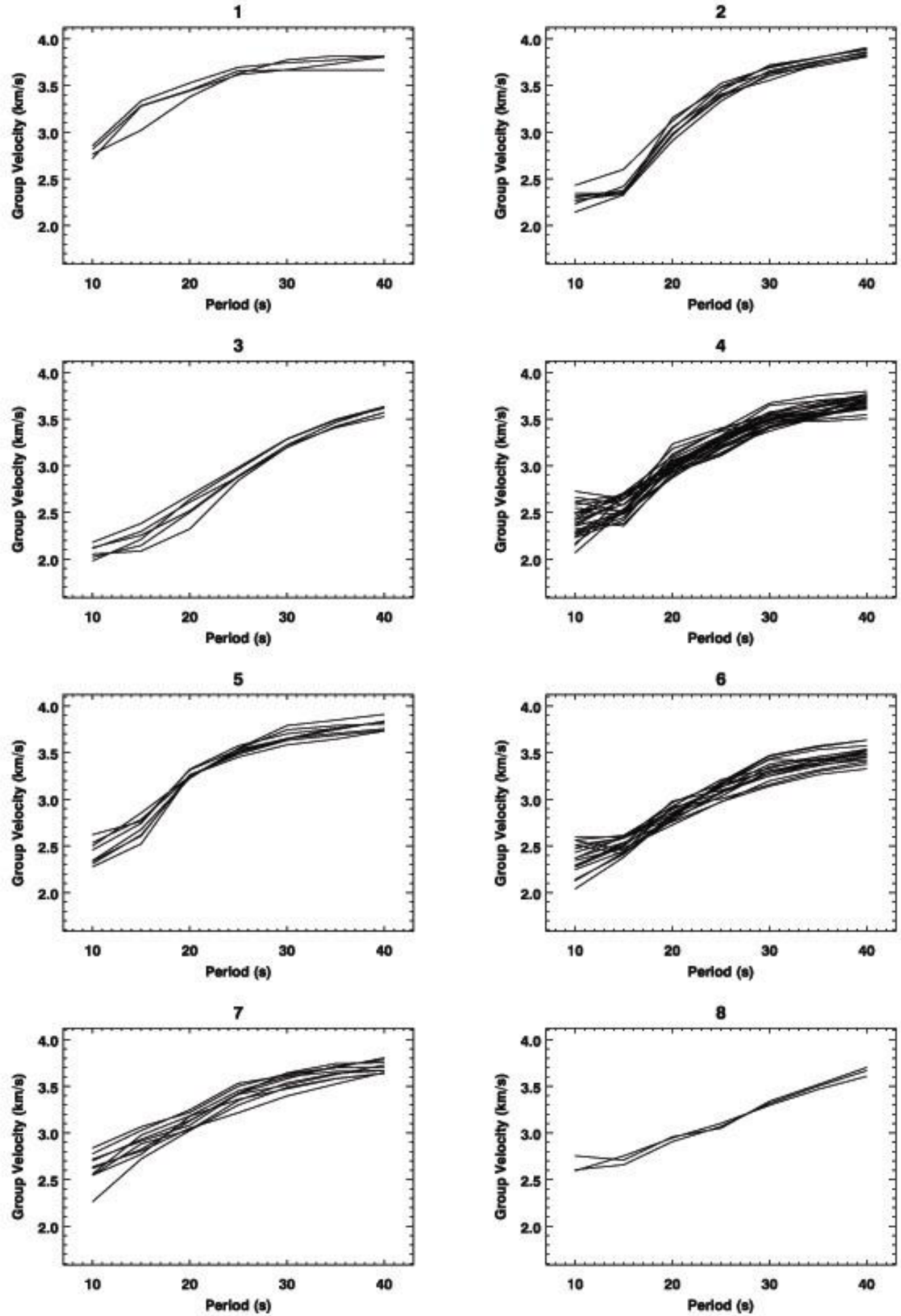

Figure 5.

The eight groups of dispersion curves obtained by the classification of the 81 curves with a similarity level $\beta_{0}=0.51$. 


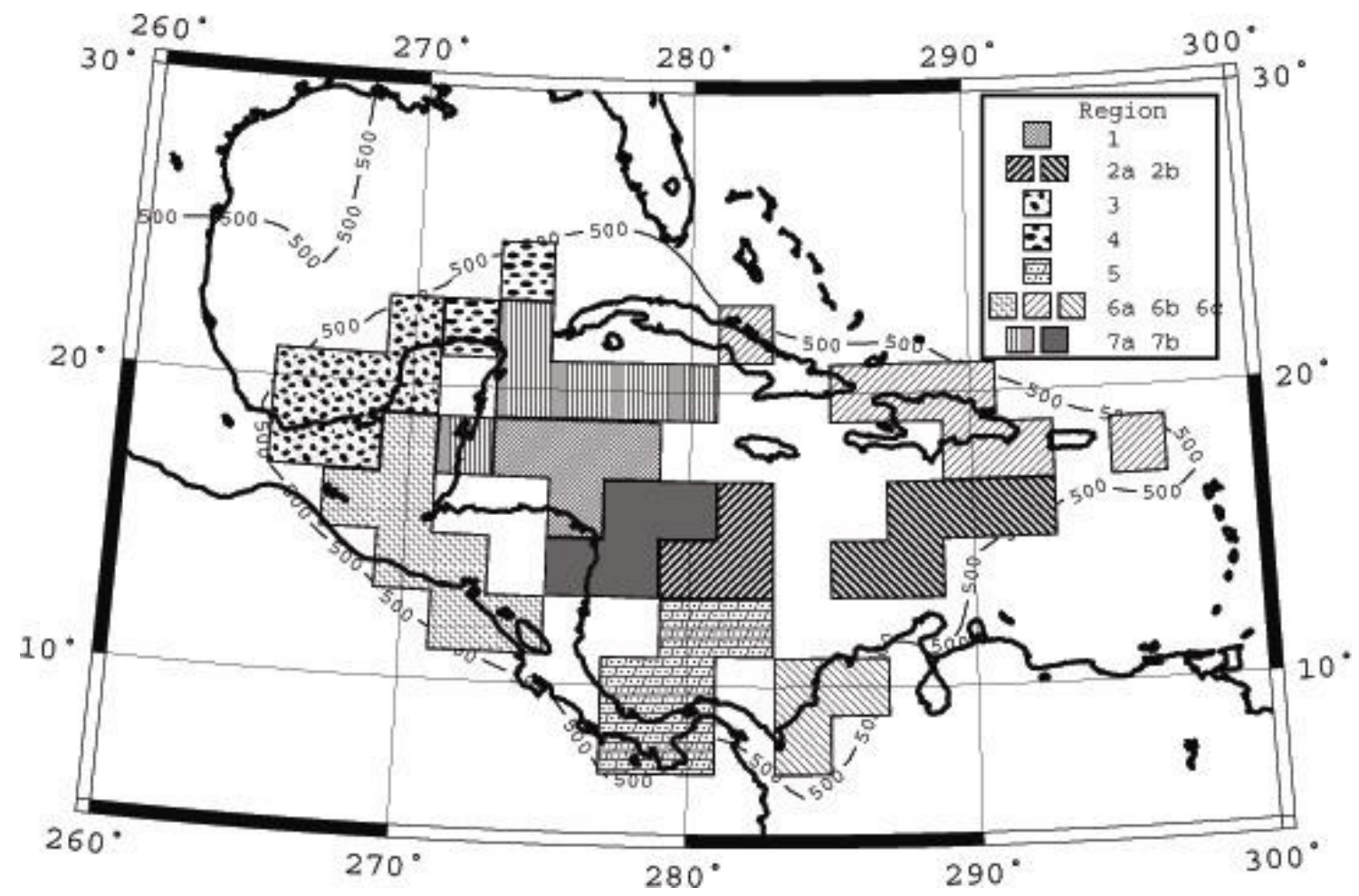

Figure 6.

Regionalization scheme: each region is identified by a different hatching. The regions named by the same number are characterized by the same dispersion curve but different, a priori known, properties. Most of the regions are compatible with the resolution length. 

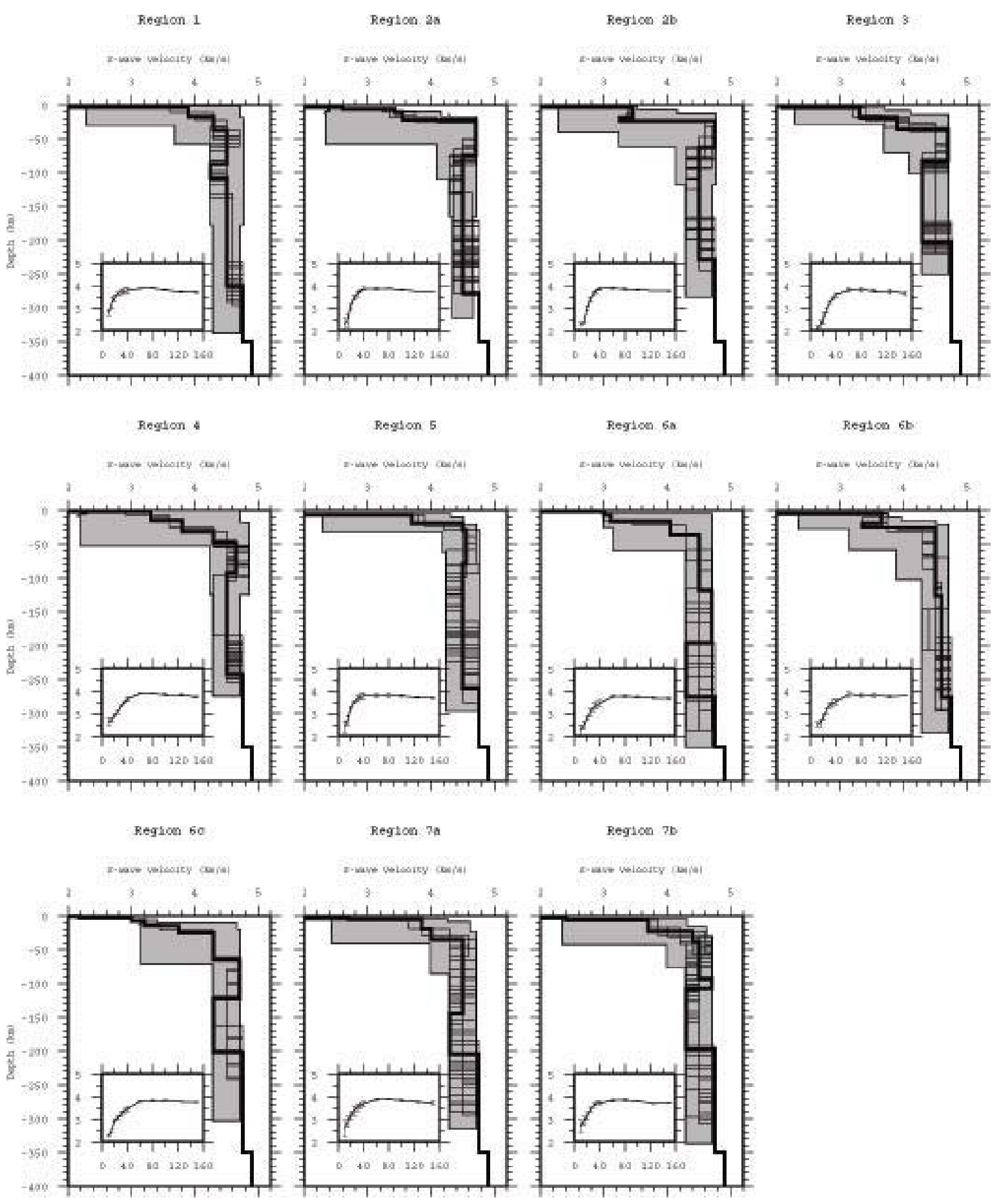

Figure 7.

The set of solutions (the S-wave velocity as a function of depth) obtained from the non-linear inversion for all the regions. A representative structural solution (see text for details) is shown by bold line and the shaded area is the portion of the parameter space explored during the inversion. In each smaller frame, the group velocity $(\mathrm{km} / \mathrm{s})$ values, as a function of the period (s), corresponding to the representative model are compared with the experimental values and their error bars. 